\title{
ANTI-PHENOLIC GLYCOLIPID-I (PGL-I) DETERMINATION USING BLOOD COLLECTION ON FILTER PAPER IN LEPROSY PATIENTS
}

\author{
Jane TOMIMORI-YAMASHITA(1), Thu H. NGUYEN(2), Solange M. MAEDA(1), Beatrice FLAGEUL(3), Osmar ROTTA(1) \& Philippe CRUAUD(4)
}

\begin{abstract}
SUMMARY
The authors studied 70 leprosy patients and 20 normal individuals, comparing the traditional sera collection method and the finger prick blood with the conservation on filter paper for specific antibodies against the native phenolic glycolipid-I (PGL-I) from Mycobacterium leprae. The finger prick blood dried on filter paper was eluated in phosphate buffer saline (PBS) containing $0.5 \%$ gelatin. The classical method for native PGL-I was performed for these eluates, and compared with the antibody determination for sera. It was observed that there is a straight correlation comparing these two methods; although the titles found for the eluates were lower than those obtained for serology. This blood collection method could be useful for investigation of new leprosy cases in field, specially in contacts individuals.
\end{abstract}

KEYWORDS: Leprosy; Diagnosis; Enzyme-linked immunosorbent assay; Finger prick (filter paper); Glycolipid (PGL-I).

\section{INTRODUCTION}

The collection of blood by venipuncture poses some problems in the field. This method requires centrifugation, and its transportation and conservation are not easy. The blood from finger prick collected on filter paper and the eluate from this blood spot could be used in place of serum. The dried samples are light, easy to store or mail, can not be broken, take up little space. The major advantage of the filter paper utilization is the facility to obtain blood samples from finger and ear lobes in children and others from whom it is difficult to get venous blood.

This technique is used in the diagnosis of various diseases for more than twenty years ${ }^{14}$. It has been developed for: arbovirus diseases ${ }^{5}$, hemoglobinopathies ${ }^{13}$, Chagas' disease ${ }^{15}$, hepatitis-B surface antigen ${ }^{12}$, amoebiasis ${ }^{17}$, and HIV (human immunodeficiency virus) antigen ${ }^{18}$.

There are many works in leprosy using this technique for specific antibody studies. Different tests have been employed, as enzyme-linked immunosorbent assay (ELISA), using synthetic phenolic glycolipid-I (PGL-I) antigen ${ }^{1,7,10,22}$, sonicated whole Mycobacterium leprae ${ }^{20}$, whole Mycobacterium smegmatis ${ }^{11}$; fluorescent leprosy antibody absorption (FLA-ABS) test ${ }^{3}$; Mycobacterium leprae particle agglutination (MLPA) test ${ }^{4,23}$; and antibody competition test with $35-\mathrm{kDa}$ soluble protein as the antigen ${ }^{19}$.

The goal of this work was to evaluate if the whole blood finger prick samples on filter paper could be used for the determination of
IgM anti-native phenolic glycolipid-I (PGL-I) antigen using an ELISA procedure. We compared these data with those obtained from sera collected by venipuncture.

\section{MATERIAL AND METHODS}

\section{Blood and sera from leprosy patients and control}

Blood samples and sera were obtained from 70 leprosy patients from the Department of Dermatology, UNIFESP-EPM, São Paulo, Brazil and from Cutaneous Diseases Clinics, Hôpital Saint-Louis, Paris, France. They were classified, according to RIDLEY \& JOPLING ${ }^{21}$, as: LL (lepromatous-lepromatous) $=35, \mathrm{BL}$ (borderline-lepromatous) $=13, \mathrm{BB}$ (borderline-borderline $)=4$, BT $($ borderline-tuberculoid $)=9$, TT $($ tuberculoid-tuberculoid $)=5$, IND (indeterminate $)=4$. Their ages ranged from 16 to 76 years (mean age $=41.5$ ), 41 males and 29 females patients were included. Fifty-one patients were treated with leprosy specific treatment. In addition, sera from 20 normal blood donors from the same hospital in São Paulo, Brazil were included as control. Their ages ranged from 18 to 47 years (mean age $=27.50$ ); 14 males and 6 females were studied.

\section{Collection of blood on filter paper and sera}

Blood was collected by finger prick without addition of any anticoagulant on filter paper cards (MN 818-filter paper, MachereyNagel, Düren, Germany). Each collection card contained four circles of $15 \mathrm{~mm}$ in diameter each one and they were covered with total blood.

(1) Departamento de Dermatologia, UNIFESP-EPM, São Paulo, Brazil.

(2) Laboratoire de Microbiologie, Hôpital Dermato-Venerologie, Ho Chi Minh Ville, Vietnam.

(3) Service de Dermatologie, Hôpital Saint-Louis, Paris, France.

(4) Service de Microbiologie, Hôpital Jean-Verdier, Bondy, France.

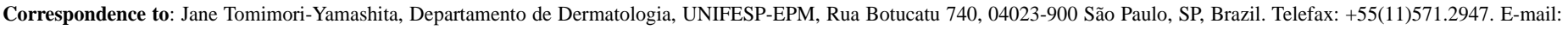
jane.derm@originet.com.br 


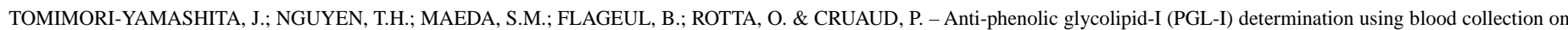
filter paper in leprosy patients. Rev. Inst. Med. trop. S. Paulo, 41 (4): 239-242,1999.

The samples were air-dried at ambient temperature for 4-5 hours, then individually wrapped in plastic wrap.

Simultaneously, blood samples were also collected from the veins for carrying out comparative studies. The sera were centrifuged and kept in aliquots.

\section{Storage of blood spots and sera}

The filter paper cards and the sera were stored at $-20{ }^{\circ} \mathrm{C}$ until they were transported on dry ice to Paris-France for testing. All the tests were carried out within a period of six months.

\section{Elution of spots}

A metal punch of $6 \mathrm{~mm}$ diameter was used to cut out the blood blots from the center of the circle. A $6 \mathrm{~mm}$ blood blot disc gave a value equivalent to $4 \mu \mathrm{l}$. The detached filter paper disc was eluated by addition of $1 \mathrm{ml}$ phosphate buffer saline (PBS) $\mathrm{pH} 7.4$ containing $0.5 \%$ gelatin (Sigma, USA) to an equivalent dilution of $1 / 250$. The eluated sample was incubated for $1 \mathrm{~h} 30 \mathrm{~min}$ at $37{ }^{\circ} \mathrm{C}$. The tube was mixed each 30 minutes (4 times).

\section{Antigen}

A native lipidic antigen: the phenolic glycolipid-I (PGL-I) of Mycobacterium leprae was used. The methods for isolation, purification and characterization were reported previously ${ }^{6}$.

\section{ELISA}

An enzyme-linked immunosorbent assay (ELISA) was performed, using the method for lipidic mycobacterial antigens, as described by CRUAUD et al. ${ }^{9}$, modified for the saturation step concerning the eluated blood from filter paper. Briefly, polystyrene microtiter plates purchased from COSTAR (USA) were coated with PGL-I (250 ng/well). For coating, the indicated amounts of antigen in $25 \mu \mathrm{l}$ of hexane were disposed in the wells, and the solutions were let to dry overnight at 37 ${ }^{\circ} \mathrm{C}$. For each determination a well treated with $25 \mu$ of hexane without antigen was used to determine non specific adsorption. The saturation step for eluated blood was done overnight at $37{ }^{\circ} \mathrm{C}$, because this procedure provided the minimal background. For the sera the saturation was done overnight at $4{ }^{\circ} \mathrm{C}$. Then, the plates were washed with PBS without Tween (Microplate washer LP 35, Diagnostics Pasteur, France). The sera were diluted $1 / 250$ in PBS containing $0.5 \%$ of porcine gelatin (Sigma, USA). After saturation by PBS containing $0.5 \%$ of porcine gelatin (overnight at $37^{\circ} \mathrm{C}$ ), the plates were washed with PBS without Tween (Micro plate washer LP 35, Diagnostics Pasteur, France). The diluted sera and the eluated blood $(100 \mu \mathrm{l})$ were incubated at $37^{\circ} \mathrm{C}$ for $2 \mathrm{~h}$. After washings, the conjugate [goat antihuman IgM (anti- $\mu$ ) $\beta$ galactosidase (Biosys, France)] with appropriate dilution was allowed to react for $2 \mathrm{~h}$ at $37{ }^{\circ} \mathrm{C}$. Then, after washing, $100 \mu \mathrm{l}$ of the substrate [2-nitrophenyl- $\beta$-D-galactopyranosid (Merck, Germany)] was added for each well, and the plates were incubated at $37{ }^{\circ} \mathrm{C}$ for $30 \mathrm{~min}$. For each plate, three titrated sera having low, medium and high levels IgM antibodies were used as standards. The PBS was used as the zero control.

The plates were read at $\Delta 405 \mathrm{~nm}$, using an automatic spectro- photometer (LP 400, Sanofi-Diagnostics Pasteur, France). The values of tested sera were corrected as follows: first, the difference between absorbance of serum or eluates and the nonspecific absorption was calculated. These values were corrected using the data obtained from the standards. For this purpose, a linear regression curve between the data and the true values of standards was calculated. If one or more of these data were not satisfactory (slope too low, correlation rate below $98 \%$ ), the plate was rejected and the assays were repeated.

The main difference between the ELISA for filter paper and the classical serology was the saturation. For serology it was done at $4{ }^{\circ} \mathrm{C}$ overnight or at $37^{\circ} \mathrm{C}$ during $2 \mathrm{~h}$. For the filter paper the saturation was modified for $37^{\circ} \mathrm{C}$ overnight. This procedure modification avoided the non specific binding, that was present in the control well, when the saturation was made at $4{ }^{\circ} \mathrm{C}$ overnight.

\section{Statistical analysis}

The comparison between the values obtained with the sera and those obtained from eluates were performed by Wilcoxon non parametric paired data test and by the correlation and the regression analysis. The calculations were made using Statview ${ }^{\mathrm{TM}} \mathrm{SE}+$ graphics (Alpha Systèmes Diffusion, France) developed for Macintosh ${ }^{\circledR}$ computer.

\section{RESULTS}

We observed a spectral distribution of anti-PGL-I antibody levels in leprosy patients. Multibacillary forms (LL, BL, BB) showed higher IgM antibody levels compared to paucibacillary form (BT and TT). The early indeterminate form included patients with positive and negative Mitsuda's reaction; in this group the antibody levels were also low, as it was found in paucibacillary forms. The control group also presented low levels of antibodies against the specific mycobacterial antigen (PGL-I). The Table 1 shows the mean value of these antibodies levels in sera and in whole blood collected on filterpaper in different forms of leprosy.

The correlation between both procedures were statistically significant $(r=0.97, p \leq 0.01)$. However, the titles obtained from eluates were lower than those obtained from the sera (Table 1). This difference was statistically significant $(\mathrm{Z}=-6.75, \mathrm{p}=0.0001)$.

The Figure 1 shows the linear regression for the paired data and indicates that the results obtained from eluates were closely related with the results obtained with the sera. The regression straight was $y=$

Table 1

Mean antibody levels against PGL-I in sera and in blood collected on filterpaper in different forms of leprosy and controls $\left(\Delta 405\right.$ OD x $\left.10^{3}\right)$ $\mathrm{OD}=$ optical density

\begin{tabular}{lccccccc}
\hline & LL & BL & BB & BT & TT & IND & Control \\
\hline Sera & 603.11 & 552.08 & 470.75 & 127.00 & 86.8 & 138.00 & 38.30 \\
Filter-paper & 465.29 & 427.85 & 430.50 & 98.67 & 67.6 & 109.75 & 33.35 \\
\hline
\end{tabular}




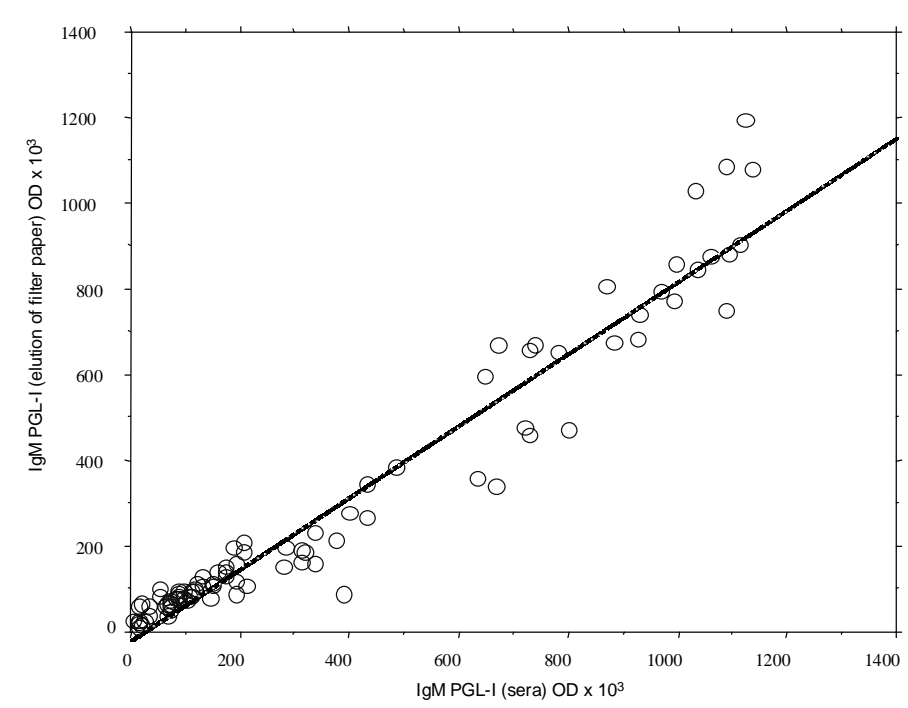

Fig.1 - Comparison of ELISA IgM anti-PGL-I paired data from whole blood collected on filter-paper versus sera $\left(\Delta 405 \mathrm{OD} \times 10^{3}\right), \mathrm{R}=0.97 ; \mathrm{p}<0.01$. (OD=optical density)

$0.836 \mathrm{x}-17.058$, indicating that the values of the eluates were about $16.4 \%$ lower than data obtained from the sera.

\section{DISCUSSION}

This work compared the results observed for the detection of antibodies anti-PGL-I in frozen serum samples obtained from venipuncture blood and whole blood eluated from filter paper disc. The sera dilution was $1 / 250$, and the eluated blood dilution was similar.

The antibody levels against PGL-I from Mycobacterium leprae detected by ELISA are useful for multibacillary leprosy diagnosis, as it had been shown by several authors ${ }^{8,9,16}$. The adaptation of this method using filter paper could be very interesting to use in field works, specially for the detection of this disease in contacts of multibacillary cases.

For the sera, a significant delay between the time of samples collection and the time of testing in the laboratory compromises the test results. Some authors have described different conditions that could modify the results; like temperature, humidity and time delay. The serology results could depend on the storing conditions. Several storage methods are described in the literature. Some authors submitted the filter paper under tropical conditions (high temperatures and humidity). They did not find any alterations in their results, even after 2 or 6 weeks of storage $\mathrm{e}^{2,19}$. However, low temperatures storing $\left(4^{\circ} \mathrm{C}\right.$ or -20 ${ }^{\circ} \mathrm{C}$ ) are recommended to obtain a good conservation of the antibody activity, even up to one year ${ }^{10,12,19}$. The purpose of this work was not to study these aspects. We decided to use the better conditions of storage: the filter papers were let to dry, disposed in plastic wraps, sent in dry ice from São Paulo to Paris and then maintained in dry atmosphere at $-20{ }^{\circ} \mathrm{C}$.

The elution of the filter paper in PBS containing $0.5 \%$ porcine gelatin for $1 \mathrm{~h} 30 \mathrm{~min}$ was enough to get the maximal values of ELISA (data not shown). Different methods were described by several authors, as: utilization of a half-normal saline with $0.1 \%$ sodium azide for the blood elution ${ }^{11}$, phosphate buffered saline (PBS) containing $3 \%$ bovine serum albumin and $0.05 \%$ Tween 20 for $2 \mathrm{~h}$ at room temperature ${ }^{10}$, PBS containing 5\% dry skimmed milk and $0.1 \%$ Tween 20 for $1 \mathrm{~h}$ at $37^{\circ} \mathrm{C} 7$, distilled water overnight at $4{ }^{\circ} \mathrm{C}{ }^{20}$, PBS containing $1 \%$ BSA and $0.1 \%$ Tween 20 for $16 \mathrm{~h}$ at room temperature ${ }^{22}$.

As it has been described in the literature, the technique using a filter paper to collect the total blood and its elution before testing for serology is a good method to substitute the classical venipuncture. The antibody anti-PGL-I concentration (as determined by the ELISA ratio index) between sera and filter paper specimens was similar. However, the obtained eluates results were lower. It suggests that described cut-off points should be modified if the method was applied on samples conserved on filter paper. The regression curve calculation indicated that the cut-off point must be around 150 in place of 200 for the sera (corrected $\Delta 405 \times 1000$ ). These observed differences could not be explained. To correct this small disadvantage it could be proposed to use a higher quantity of dried blood, but this procedure would increase the background of this method (data not shown).

Several works had shown that the collection of blood on filter paper is a good alternative method to quantify anti-mycobacterial antibodies concentration $^{1,3,4,12,17,18,20,22,23}$. This procedure had not been yet explored with ELISA using the native phenolic glycolipid of Mycobacterium leprae (PGL-I).

Analyzing the different forms of leprosy, we could observe a spectral distribution of anti-PGL-I antibodies levels in the blood collected on filter paper, as it has been described in classical serology using this native antigen. This work showed the correspondence between these two methods of anti-Mycobacteria antibodies detection. The antibodies titers allow the differentiation between pauci and multibacillary forms of leprosy. In this study we have not included enough number of indeterminate form patients for comparison with other forms, although we could observe that the antibodies levels were not as high as they were found in multibacillary patients.

In conclusion, the analysis of eluates from the whole blood collected on filter paper could substitute the traditional serology, as the reproducibility of the ELISA for anti-PGL-I is very good. This technique for collecting blood could be useful in leprosy field investigation. Particularly in developing countries, as it is a cheap and easy method for collecting, storing and transporting the material.

\section{RESUMO}

\section{Determinação do anti-PGL-I (glicolípide fenólico I) utilizando sangue coletado em papel-filtro nos doentes com hanseníase}

Os autores estudaram 70 doentes com hanseníase e 20 indivíduos normais e compararam o método tradicional de coleta de soro com o método de coleta e conservação de sangue em papel-filtro, dosando os níveis de anticorpos específicos contra o glicolipídio fenólico-I (PGLI) do Mycobacterium leprae. O papel-filtro com o sangue a ser experimentado foi eluído em tampão fosfato (PBS) contendo $0,5 \%$ de 
TOMIMORI-YAMASHITA, J.; NGUYEN, T.H.; MAEDA, S.M.; FLAGEUL, B.; ROTTA, O. \& CRUAUD, P. - Anti-phenolic glycolipid-I (PGL-I) determination using blood collection on filter paper in leprosy patients. Rev. Inst. Med. trop. S. Paulo, 41 (4): 239-242,1999.

gelatina. O método clássico para o PGL-I nativo foi realizado nesta solução, comparando-se com a determinação dos anticorpos no soro. Uma correlação positiva foi observada, comparando-se os dois métodos, embora os títulos encontrados na solução obtida através da eluição do sangue coletado em papel-filtro foram menores que os obtidos pelo método sorológico. Este método de coleta de sangue em papel-filtro pode vir a ser útil na investigação de novos casos de hanseníase em trabalhos de campo, em particular no estudo de comunicantes.

\section{ACKNOWLEDGMENTS}

This work was partially supported by CNPq (Conselho Nacional de Desenvolvimento Científico e Tecnológico) - Brazil, that provided a scholarship for the first author.

\section{REFERENCES}

1. AGUADO-SANCHEZ, G.; MALIK, A.; TOUGNE, C.; LAMBERT, P.H. \& ENGERS H.D. - Simplification and standardization of serodiagnostic tests for leprosy based on phenolic glycolipid-I (PGL-I) antigen. Leprosy Rev., 57 (suppl.2): 83-93, 1986.

2. BEHETS, F.; KASHAMUKA, M.; PAPPAIOANOU, M. et al. - Stability of human immunodeficiency virus type 1 antibodies in whole blood dried on filter paper and stored under various tropical conditions in Kinshasa, Zaire. J. clin. Microbiol., 30: 1179-1182, 1992

3. BHATIA, V.N.; SUDARSANAM, D. \& ROY, R.G. - Use of Whatman chromatography paper for serological studies in leprosy in the field. Indian J. Leprosy, 57: 341$345,1985$.

4. BHATIA, V.N.; CHAKRABORTY, S.; MUKHERJEE, B.; PANDA, S.N. \& CHAKRABORTY, T.K. - Application of filter paper method for collection of blood for MLPA test. Indian J. Leprosy, 65: 207-210, 1993.

5. BOND, J.O.; LEWIS, A.L.; GATES, E.H. \& McLENDON, S.S. - Filter paper disc method of collecting whole blood for arbovirus serologic surveys in adults. Hlth. Lab. Sci., 6: $168-172,1969$.

6. BRENNAN, P.J. \& BARROW, W.W. - Evidence for species-specific lipid antigens in Mycobacterium leprae. Int. J. Leprosy, 48: 382-387, 1980.

7. CHANTEAU, S.; PLICHART, R.; BOUTIN, J.-P.; ROUX, J. \& CARTEL, J.-L. - Fingerprick blood collection and computer-assisted enzyme-linked immunosorbent assay for large-scale serological studies on leprosy. Trans. roy. Soc. trop. Med. Hyg., 83: 414-416, 1989.

8. CHO, S.-N.; YANAGIHARA, D.L.; HUNTER, S.W.; GELBER, R.H. \& BRENNAN, P.J. - Serological specificity of phenolic glycolipid I from Mycobacterium leprae and use in serodiagnosis of leprosy. Infect. Immun., 41: 1077-1083, 1983.

9. CRUAUD, P.; YAMASHITA, J.T.; CASABONA, N.M.; PAPA, F. \& DAVID, H.L. Evaluation of a novel 2,3-diacyl-trehalose-2'-sulphate (SL IV) antigen for case finding and diagnosis of leprosy and tuberculosis. Res. Microbiol., 141: 679-694, 1990.

10. DHANDAYUTHAPANI, S.; ANANDAN, D.; VASANTHI, B. \& BHATIA, V.N. - Use of eluates of filter paper blood spots in ELISA for the serodiagnosis of leprosy. Indian J. med. Res., 89: 150-157, 1989.

11. DOUGLAS, J.T. \& WORTH, R.M. - Field evaluation of an ELISA to detect antibody in leprosy patients and their contacts. Int. J. Leprosy, 52: 26-33, 1984.

12. FARZADEGAN, H.; NOORI, K.H. \& ALA, F. - Detection of hepatitis-B surface antigen in blood and blood products dried on filter paper. Lancet, I: 362-363, 1978

13. GARRICK, M.D.; DEMBURE, P. \& GUTHRIE, R. - Sickle-cell anemia and other hemoglobinopathies. New Engl. J. Med., 288: 1265-1268, 1973.

14. GUTHRIE, R. \& SUSI, A. - A simple phenylalanine method for detecting phenylketonuria in large populations of newborn infants. Pediatrics, 32: 338-343, 1963

15. KAGAN, I.G.; GOLDSMITH, R.S.; ZÁRATE-CASTAÑEDA, R. \& ALLAIN, D.S. Evaluation of serologic tests for studies on Chagas' disease. Bull. Pan Amer. Hith. Org., 12: 341-348, 1978

16. LEVIS, W.R.; MEEKER, H.C.; SCHULLER-LEVIS, G.; SERSEN, E. \& SCHWERER, R. - IgM and IgG antibodies to phenolic glycolipid I from Mycobacterium leprae in leprosy: insight into patient monitoring, erythema nodosum leprosum, and bacillary persistence. J. invest. Derm., 86: 529-534, 1986.

17. MATHEWS, H.M.; SPENCER, H.C. \& HEALY, G.R. - Comparison of IHA test for amoebiasis on serum and filter paper specimens. Trans. roy. Soc. trop. Med. Hyg., 74: 404-405, 1980

18. NIELSEN, C.M.; BYGBJERG, I.C. \& VESTERGAARD, B.F. - Detection of HIV antigens in eluates from whole blood collected on filterpaper. Lancet, I: 566-567, 1987.

19. PATIL, S.A.; RAMU, G.; SINHA, S. \& SENGUPTA, U. - Screening of anti-M. leprae antibodies in the blood samples eluted from filter paper blood blots. Int. J. Leprosy, 58: $123-126,1990$.

20. QIN-XUE, W.; GAN-YUN, Y.; LI-LIN, Z. et al. - Determination of antibodies in dried blood from earlobes of leprosy patients by enzyme-linked immunosorbent assay: a preliminary report. Int. J. Leprosy, 53: 565-570, 1985.

21. RIDLEY, M.J. \& JOPLING, W.H. - A classification of leprosy for research purposes. Leprosy Rev., 33: 119-128, 1962.

22. SAHASRABUDHE, R.; DANDEKAR, S.; SHAH, D.H.; NAIK, S. \& GANAPATHI, R - Filter paper blood spot test for detection of anti-ND-BSA antibodies in school children. Indian J. med. Res., 95: 105-111, 1992.

23. SEKAR, B. \& ANANDAN, D. - Evaluation of Mycobacterium leprae particle agglutination test, using eluates of filter paper blood spots. Leprosy Rev., 63: 117 $124,1992$.

Received: 26 January 1999

Accepted: 11 June 1999 